\title{
THE OAK CHRONOLOGY (948-1314 AD) FOR THE ŻARY AREA (SW POLAND)
}

\author{
MALGORZATA DANEK, MARZENA KLUSEK and MAREK KRĄPIEC \\ AGH - University of Science and Technology, Faculty of Geology, \\ Geophysics and Environmental Protection, \\ 30-059 Cracow, Mickiewicza 30, Poland
}

Received 9 November 2006

Accepted 22 December 2006

\begin{abstract}
The study presents the results of investigations aimed at construction of a site chronology for oak wood from the surroundings of Żary (SW Poland). The 366-year chronology ZY 2006, covering the period 948-1314 $\mathrm{AD}$ was determined on the basis of 189 individual ring patterns representing samples of archaeological wooden objects lifted at the excavation works led in the Old Town of Żary in the years 2004-2005. The chronology produced exhibits high similarity to the standards for the neighbouring regions: Wielkopolska and Lower Silesia. The statistical parameters of the chronology are very high and, thanks to the signature years determined, it should be an excellent tool for dating samples of mediaeval timbers from the whole region of Ziemia Lubuska, including some with relatively short dendrochronological sequences.
\end{abstract}

Keywords: dendrochronological standard, tree-ring analysis, Quercus sp., Żary, SW Poland

\section{INTRODUCTION}

The dendrochronological dating, together with the radiocarbon method, belongs to the most frequently used methods of dating wood. Although the dendrochronological method has been being developed in Poland for over twenty years, there are still such regions in the country, for which there has not been yet elaborated appropriate network of local chronologies, enabling dating wood samples with short ring patterns as well as identification of the origin of wood. One of such areas was the region of Ziemia Lubuska. Dendrochronological analyses of wood from that region were made only occasionally, with dating against regional standards constructed for the neighbouring areas: Wielkopolska (449-1998 AD) and Lower Silesia (780-1997 AD; Krapiec, 1998).

Hitherto performed dendrochronological analyses of timbers from the Ziemia Lubuska region dealt with wood samples coming from older archaeological excavations led in Międzyrzecz and Świebodzin (Krąpiec, 1998) and individual elements of wooden structures lifted at rescue

Corresponding author: M. Krapiec

e-mail: mkrapiec@geol.agh.edu.pl

ISSN 1897-1695 (online) C 2007 GADAM Centre,

Institute of Physics, Silesian University of Technology.

All rights reserved. excavations in Lubsko, Krosno Odrzańskie and Kożuchów. In the course of these analyses, problems arose with dating individual samples of relatively low number of tree rings (around 50-60); such problems are rather common in such contexts. In the last years (2004-2005), this uncomfortable situation substantially improved, thanks to archaeological excavations preceding construction works within the Old Town of Żary, at which several hundred pieces of mediaeval wood were collected. Abundant, well-preserved wooden structures were exhaustively sampled, and the produced dendrochronological sequences resulted in construction of a site chronology for oak from the surroundings of Żary, presented in this study.

\section{MATERIAL}

The research material were timbers sampled at archaeological works led within the Old Town of Żary in the years 2004-2005, which revealed fragments of posts, beams and radial planks from mediaeval wooden buildings loosely dispersed in the analysed cultural and historical layers. 


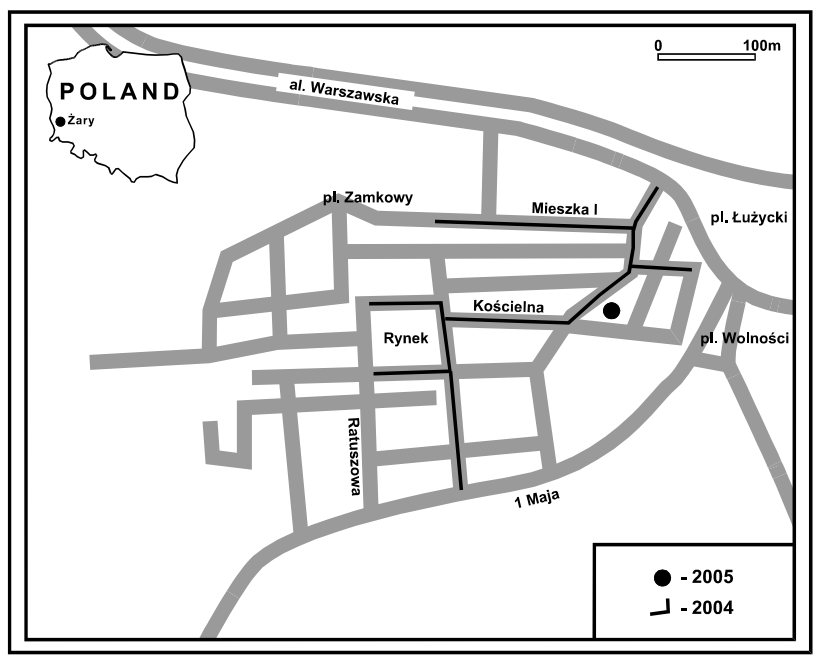

Fig. 1. Location of the archaeological rescue excavations in the Old Town of Żary.

The first batch of timbers - 90 samples, came from rescue excavations connected with modernization of the sewage network in the eastern part of the Old Town at the streets Traugutta, Mieszka I, Kościelna, and Rynek (Market Square), led by T. Nowiński in 2004. The next batch of samples, considerably more numerous (378 pieces), came from rescue works preceding modernization of the Tax Office building, situated on the ground division no 368/1 at the Osadników Wojskowych street. This area covers a whole quarter of historic buildings at one of main streets of the mediaeval town of Żary (Fig. 1). The excavations, directed by K. Kamiński, were carried out by Alina Jaszewska Archaeological and Conservatory Studio (Kamiński, 2005).

Altogether as many as 468 samples of various tree species in the form of slices and/or wedges were available for the analysis. Such mode of sampling is the most convenient, because of relatively large surfaces of the transverse cross-sections, giving the possibility of tree-ring measurements along several radii.

The anatomical analysis of these 468 wood samples enabled to recognise 277 fragments of the oakwood (Quercus sp.), 96 of pine wood (Pinus sylvestris L.), 48 of fir (Abies alba Mill.), 33 of alder (Alnus sp.), as well as two of beech (Fagus sylvatica L.), two of elm (Ulmus sp.), one piece of limewood (Tilia sp.), three of poplar (Populus sp.) and six fragments of willow wood (Salix sp.).

For dendrochronological studies samples with legible, undisturbed growth patterns and at least 25 tree-rings were selected. Hence, measurements were made on 268 pieces of oakwood, 82 of pine wood, 41 of fir wood, as well as one piece of beech wood and seven samples of alder. The results of dating of the remaining tree species will be presented in a separate paper.

\section{METHODS}

Samples of oakwood fulfilling the requirements of the dendrochronological method were subjected to suitable preparation. In order to obtain legible structure of tree rings the timbers were cut in the plane of the transverse cross-section of trunks. For each sample measurements were carried out along two or three radii, with the DENDROLAB 1.0 apparatus allowing for determination of tree-ring widths with $0.01 \mathrm{~mm}$ accuracy. The measurement data were registered with the program QUERCUS (Walanus, 2005). Correlation and averaging of the growth sequences produced were made with the computer program package TREE-RINGS, on the basis of calculations of the Pearson's linear correlation coefficient and the coefficient ' $t$ ' (Krawczyk and Krapiec, 1995). The calculated correlation of sequences was also checked by visual matching of the dendrograms. Based on the contemporary sequences of individual samples the site chronology was compiled. The correctness of the chronology construction was checked with the program COFECHA (Holmes, 1999). Absolute dating of the chronology was made against the existing regional standards. On the basis of the correlation with the site chronology and mutual comparison of the remaining dendrochronological sequences, most of the remaining oak samples from the excavations were absolutely dated.

Individual sequences forming the newly produced oak chronology were subjected to the standardization procedure (Fritts, 1976). Transformation of individual sequences into the standardized ones was carried out with the computer program ARSTAN (Cook and Holmes, 1986; Cook, 1995). A function depicting the trend line was one of the spline varieties (cubic spline), estimated in the window of length equal to $2 / 3$ of average length of growth sequences of samples forming the chronology; 77 years in the case of the oak chronology. Mutually correlated and averaged, indexed growth sequences formed socalled standardized chronology. The residual chronology was constructed as a standardized chronology transformed with the autoregression model (Cook and Kairiukstis, 1990).

For the chronologies created, the average correlation between all series was calculated (RBAR, $r_{b t}$ ), which expresses the strength of the useful, climatic signal. The parameter was calculated in a 50-year moving window, starting from the year, in which the number of trees forming the chronology amounted to at least four (Wigley et al., 1984; Cook and Kairiukstis, 1990). In order to check the credibility of the chronology, the EPS value (Expressed Population Signal) was also calculated (Wigley et al., 1984; Cook et al., 2002). Analysis of the RBAR and EPS values enables to check whether the constructed chronology is enough reliable along its whole length (Cook and Kairiukstis, 1990; Cook et al., 2002).

On the basis of all growth sequences forming the chronology signature years were determined (Schweingruber, 1992; Schweingruber et al., 1990). Calculations were carried out with the program QUERCUS (Walanus, 2005). Only such years were taken into account, in which a decline or an increase of annual increments was noted in at least $90 \%$ out of at least 10 analysed sequences (Zielski and Krąpiec, 2004). 
M. Danek et al.

Table 1. Comparison of basic parameters for the raw, standardized, and residual chronologies for oak.

\begin{tabular}{rccccc}
\hline & Standard deviation & Mean sensitivity & First-order autocorrelation & RBAR & EPS \\
\hline Raw chronology & 0.240 & 0.110 & 0.705 & 0.320 & 0.934 \\
Standardized chronology & 0.126 & 0.112 & 0.378 & 0.336 & 0.934 \\
Residual chronology & 0.113 & 0.131 & -0.057 & 0.356 & 0.945 \\
\hline
\end{tabular}

\section{RESULTS}

Out of 268 growth sequences of oak, 189 most convergent ones were selected, and on that basis the 366-year chronology ZY 2006 was determined. Characteristics of statistical parameters for the raw, standardized and residual chronologies are given in Table 1. It should be noted that low mean sensitivity and, in turn, relatively high autocorrelation coefficient for the raw chronology indicate occurrence of long-term fluctuations, mostly not related to the climate. This parameter is better in the standardized and residual chronologies.

For absolute dating, the site chronology produced was compared with the regional chronologies for neighbour-

Table 2. Comparison of signature years for the chronology for Żary (ZY_2006) and the standard chronologies for the regions of Wielkopolska (WPL_1) and Lower Silesia (DSL_1).

\begin{tabular}{|c|c|c|c|}
\hline & ZY_2006 & WPL_1 & DSL_1 \\
\hline 999 & + & & \\
\hline 1002 & + & & \\
\hline 1005 & + & & \\
\hline 1013 & + & & \\
\hline 1023 & + & & \\
\hline 1030 & + & + & + \\
\hline 1034 & - & & \\
\hline 1052 & + & + & \\
\hline 1053 & - & - & \\
\hline 1069 & - & & \\
\hline 1070 & - & - & \\
\hline 1076 & + & & \\
\hline 1078 & - & & - \\
\hline 1081 & - & & \\
\hline 1082 & + & + & \\
\hline 1118 & + & + & \\
\hline 1130 & + & & \\
\hline 1142 & - & & - \\
\hline 1143 & + & & + \\
\hline 1168 & + & + & \\
\hline 1178 & + & & \\
\hline 1186 & + & + & + \\
\hline 1209 & - & & \\
\hline 1217 & - & & \\
\hline 1231 & - & & - \\
\hline 1245 & + & & \\
\hline 1267 & - & & \\
\hline 1270 & - & & \\
\hline
\end{tabular}

ing areas, namely, the Wielkopolska chronology WPL_1, spanning over years 449-1998 AD, and the Lower Silesia chronology (DSL_1), representing the period 780-1997 AD (Krapiec, 1998). The chronology for Żary exhibited very high convergence with both these chronologies (with the standard DSL_1: $t=12.1, r=$ 0.538; and with the chronology WPL 1: $t=10.3, r=$ 0.476 ), for the period $948-1314 \mathrm{AD}$. This demonstrates not only the correctness of its construction but also local origin of wood used for construction of the objects investigated.

Fig. 2 presents coverage of time by the sequences forming the chronology. It is clear, that in most of the time the chronology is determined by several tens of samples. Only at the beginning and in the last years (948$993 \mathrm{AD}$ and 1285-1314 AD) the number of samples falls below ten.

The average value of the useful signal (RBAR) calculated for the constructed standardized chronology amounts to 0.336 . Calculation of this coefficient was possible for the period 982-1290 AD. Reliability of the chronology in this time interval is confirmed by the EPS values. The average value of this parameter is very high, amounting to 0.934. Except for a few short, several-year periods at the beginning and end of the chronology, the EPS is higher than 0.85 - a value commonly assumed as satisfactory (Fig. 3; see Cook and Kairiukstis, 1990). It should be added that the EPS fluctuations in time depend on the number of sequences forming the chronology in a given year, which undoubtedly affect distinct decline of this parameter in several years at the beginning and at the end, where the number of samples is lower.

Table 2 presents signature years calculated for the oak chronology for Żary (ZY_2006), together with the same signature years observed in the standard chronologies WPL_1 and DSL_1. It transpires, that out of 28 distinguished signature years (16 positive and 12 negative), twelve coincide with the signatures, which appeared in one or the other regional standard. The comparison indicates, that the coinciding signatures present around $43 \%$ of such years observed in the chronology produced. Relatively high number of signature years present in the chronology for Żary, but not-observed in both standards should be related to the fact that in the case of local sequences, the occurrence of signatures depends on many factors of only local impact. In the case of regional chronologies constructed on the basis of many local ones, locally distinguished signatures are levelled; however, those resulting from the effects of factors of regional character are emphasized. It is worth adding that there were no cases where a positive year observed in the sequence Żary would be a negative one in any of the standards, which points out the correctness of dating, as well as similarity of these chronologies. 




Fig. 2. Block-diagram of the dendrochronological sequences from the Old Town in Żary forming the chronology ZY_2006 (sapwood marked with dark cross-hatching). 


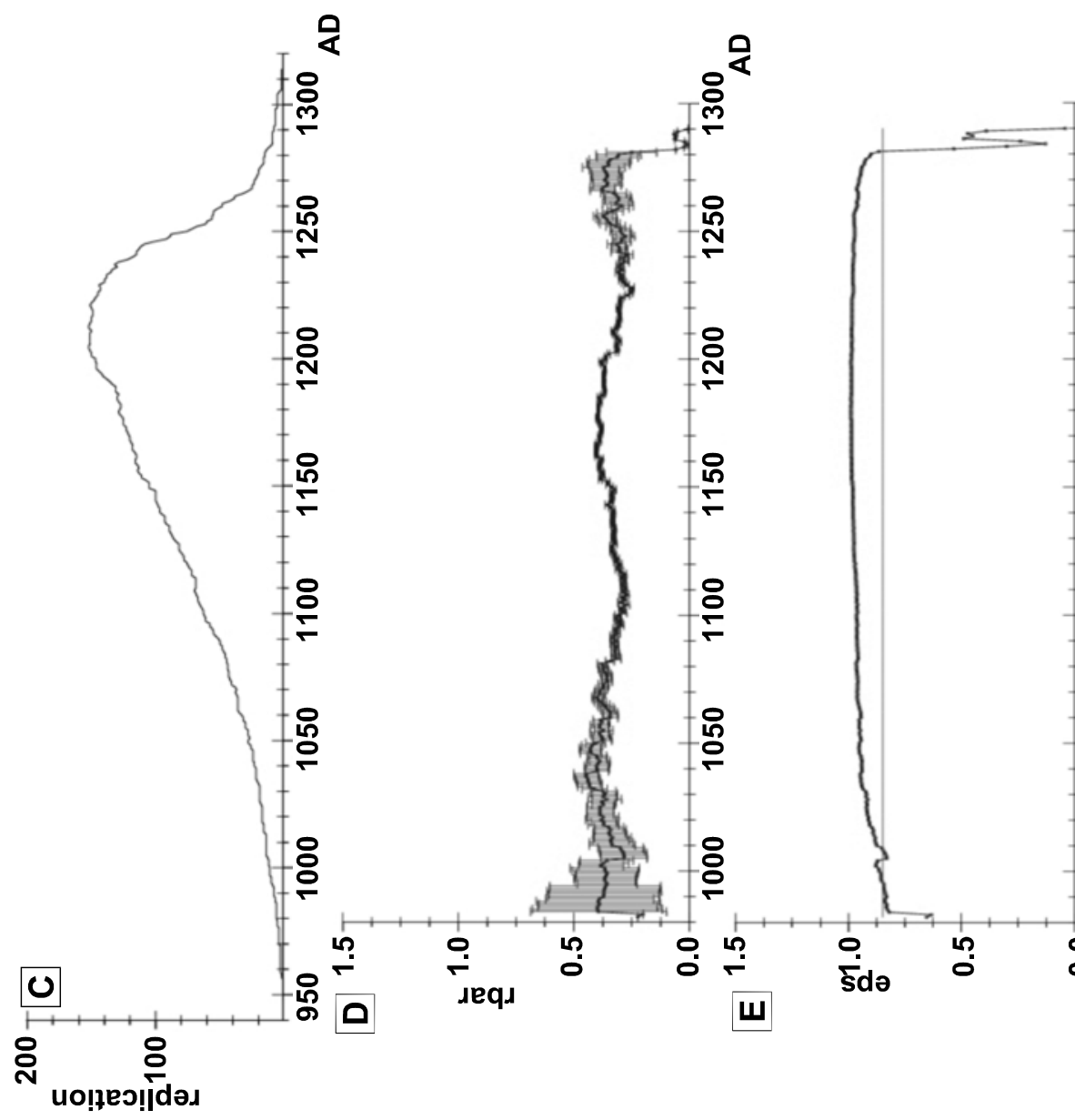

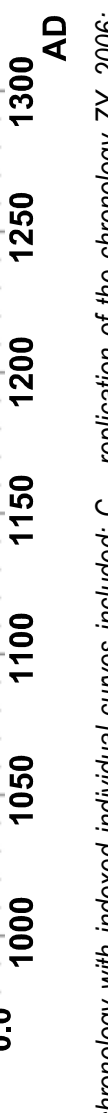

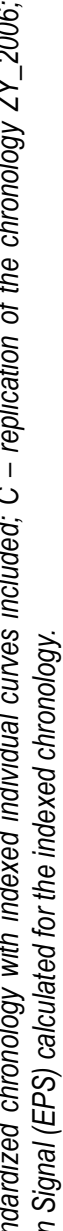

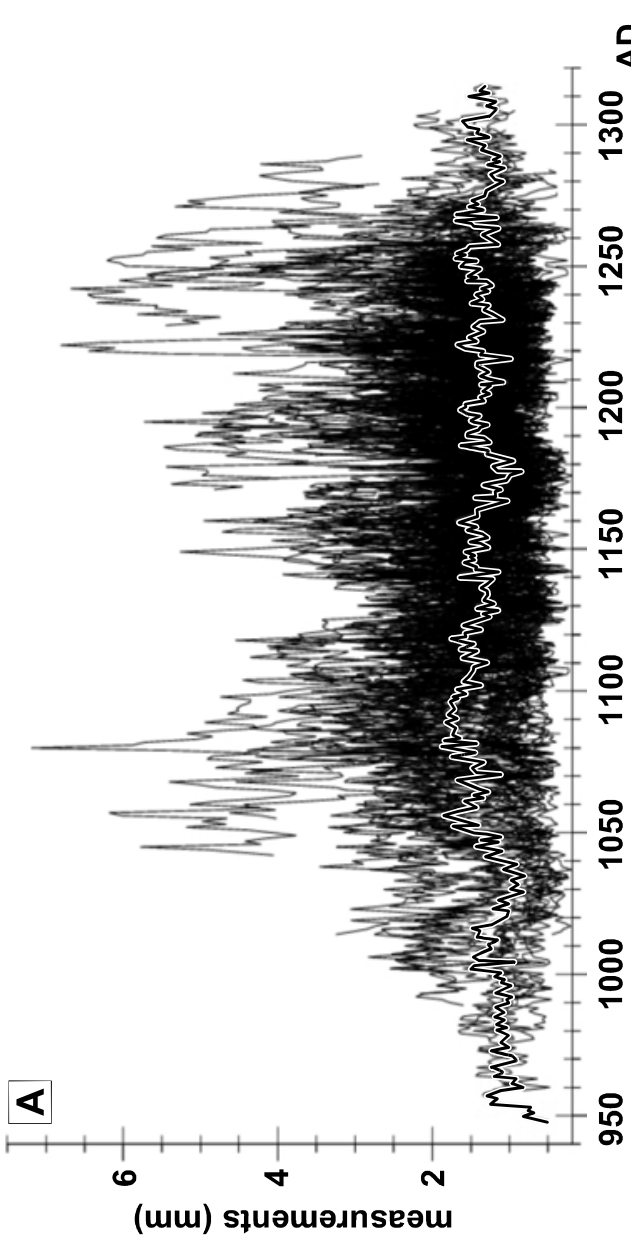

\%

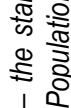
$12 \frac{0}{8}$ ذं क् 월 넌 \& ¿ क षे

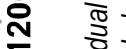

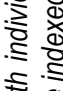
요 ठे̀ 응 원 요웡 究

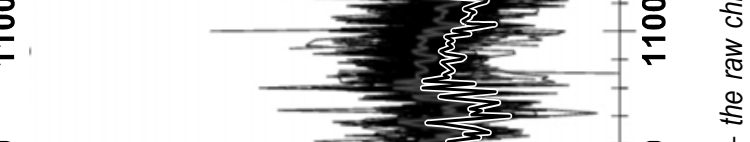

융 究

윤단

용

- స

응 장

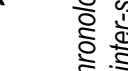
유 용 ले 운 
Finding causes of the occurrence of signature years is a difficult task, often it is literally impossible. This particularly concerns chronologies based on old wood, e.g. coming from archaeological excavations, because of scarce information about its origin. In such cases one can only base on rare historical notes concerning weather and its anomalous events, like drought or flood. As to the chronology produced, in two cases it was possible to tie the signature years with phenomena described in literature. Positive year 1118 AD could be related to particularly humid vegetation seasons, what is indicated by historic notes about floods and river overflows registered all over Poland. Negative signature year 1069 AD could be connected with very heavy winter in the region of Lusitania (Girguś and Strupczewski, 1965). Positive signatures are often connected with the years with high rainfall in the vegetation season, additionally preceded by mild winter. Negative years usually result from dry summers, preceded by severe winters. Such relations are characteristic for all Polish oaks (Krapiec, 1998).

\section{CONCLUSIONS}

The timber used for construction of objects of the medieval town of Żary probably came from not very large acreage, so it is possible to consider the average pattern ZY_2006 as a local chronology for the surroundings of Żary. Without doubt it is a very good starting point for elaboration of the dendrochronological standard for the whole region of Ziemia Lubuska. Thanks to high statistical parameters and the signature years determined it the presented chronology is an excellent dating tool for local wood, substantially better than the hitherto used standards for the adjacent, but dendrochronologically relatively distant regions.

\section{ACKNOWLEDGMENTS}

Financial support for this study was provided by the AGH-UST grant no 11.11.140.917.

\section{REFERENCES}

Cook ER, 1995. ARSTAN. Dendrochronology Program Library.

Cook ER and Holmes R, 1986. Users manual for program ARSTAN. University of Arizona, Tucson.

Cook ER and Kairiukstis A, 1990. Methods of dendrochronology Applications in environmental sciences. Kluwer Academic Publishers: 394pp.

Cook ER, Palmer JG, Cook BI, Hogg A and D'Arrigo RD, 2002. A multi-millennial palaeoclimatic resource from Lagarostrobos colensoi tree-rings at Oroko Swamp, New Zealand. Global and Planetary Change 33: 209-220.

Fritts HC, 1976. Tree Ring and Climate. Academic Press, London: $567 \mathrm{pp}$.

Girguś R and Strupczewski W, 1965. Wyjątki ze źródeł historycznych o nadzwyczajnych zjawiskach hydrologiczno-meteorologicznych na ziemiach polskich w wiekach od X do XVI (Excerptions from historical sources about hydrological-meteorological phenomena in Polish lands in X-XVI centuries). Warszawa: 214pp (in Polish).

Holmes RL, 1999. Users Manual for Program COFECHA. University of Arizona, Tucson.

Kamiński K, 2005. Sprawozdanie z ratowniczych badań wykopaliskowych na działce nr 368/1 w Żarach przy ulicy Osadników Wojskowych (Exhaustive archaeological rescue works on area nr 368/1 in Zary at Osadnikow Wojskowych Street - report). Zielona Góra 2005 (in Polish).

Krawczyk A and Krapiec M, 1995. Dendrochronologiczna baza danych (Dendrochronological database). Materiały II Krajowej Konferencji: Komputerowe wspomaganie badań naukowych. Wrocław: 247-252 (in Polish).

Krapiec M, 1998. Oak dendrochronology of the Neoholocene in Poland. Folia Quaternaria 69: 5-133.

Schweingruber FH, 1992. Event years and pointer years. Tree rings and environment, Proccedings of the International Dendrochronological Symposium (LUNDQUA Report 34), Ystad, South Sweden, 39 September 1990: 288-292.

Schweingruber FH, Eckstein D, Serre-Bachet F and Bräker OU, 1990. Identification, presentation and interpretation of event years and pointer years in dendrochronology. Dendrochronologia 8: 9-37.

Walanus A, 2005. Program Quercus. Instrukcja obsługi (Quercus. Users manual). Krakow (in Polish).

Wigley TML, Briffa KR and Jones PD, 1984. On the value of correlated time series, with applications in dendroclimatology and hydrometeorology. Journal of Climate and Applied Meteorology 23: 201213

Zielski A and Krapiec M, 2004. Dendrochronologia (Dendrochronology). Wydawnictwo Naukowe PWN. Warszawa: 328pp (in Polish). 